\title{
Physical Characterization of Batie and Bandjoun-Djione Sands (West-Cameroon), Used in the Manufacture of Concrete: Improvement of Resistance to Compression
}

\author{
Jules H. Keyangue Tchouata1, Casimir Gouafo²*, Grégoire Kamdjo², François Ngapgue², \\ Armand S. L. Wouatong 3 \\ ${ }^{1}$ School of Geology and Mining Engineering, University of Ngaoundere, Ngaoundere, Cameroon \\ ${ }^{2}$ Fotso Victor Institute of Technology, University of Dschang, Dschang, Cameroon \\ ${ }^{3}$ Faculty of Sciences, University of Dschang, Dschang, Cameroon \\ Email: keytchjmann@yahoo.fr, fgapguefcr@gmail.com, kamdjog@yahoo.fr, *casimirgouafo@yahoo.fr, aslwouat@yahoo.com
}

How to cite this paper: Tchouata, J.H.K., Gouafo, C., Kamdjo, G., Ngapgue, F. and Wouatong, A.S.L. (2020) Physical Characterization of Batie and Bandjoun-Djione Sands (West-Cameroon), Used in the Manufacture of Concrete: Improvement of Resistance to Compression. Journal of Materials Science and Chemical Engineering, 8, 10-20.

https://doi.org/10.4236/msce.2020.85002

Received: March 24, 2020

Accepted: May 16, 2020

Published: May 19, 2020

Copyright $\odot 2020$ by author(s) and Scientific Research Publishing Inc. This work is licensed under the Creative Commons Attribution International License (CC BY 4.0).

http://creativecommons.org/licenses/by/4.0/

\section{(c) (i) Open Access}

\begin{abstract}
The objective of this work, was to characterize the sands of the quarries of: Bandjoun-Djione, Djengou, Hiala and La'gou I, mainly from their mechanical strengths, the equivalent of sand and the finesse module. In order to study the compressive strength of concrete made from these sands, we determined their granularity, fineness modulus and density; the concrete was then formulated by the Dreux-Gorisse method. A total of 72 specimens were constructed with the objective of achieving an average compressive strength of $25 \mathrm{MPa}$ at 28 days. But we have obtained a compressive strength at 28 days, varying from 13.14 MPa to 17.50 MPa. The correction of the modulus of fineness of these sands made it possible to improve the granularity and increase the compressive strength of these concretes by more than $70 \%$. We have thus obtained the compression resistance of $25 \mathrm{MPa}$ aimed for each of the corrected sands.
\end{abstract}

\section{Keywords}

Sand, Granulometry, Concrete, Mechanical Resistance, Djengou, Hiala, La'gou I, Bandjoun-Djione

\section{Introduction}

Sands are materials, the grain size of which is between 0.08 and $5 \mathrm{~mm}$ [1], which are widely used for the construction of civil engineering works. Their main 
component is quartz, the density of which is around 2.65. In West Cameroon, urbanization, the growing need for construction, and new building, have generated, the artisanal extraction of sand, and powerful weathering coats, developed at the expense, of subject rocks, with a tropical climate [2]. These sands are extracted and used, regardless of their quality. This results in serious, and often catastrophic, consequences for the structures: poor behavior of plasters, coating of walls, cracking, and crumbling of beams, and lintels, with exposure of the reinforcement, in the case of reinforced concrete; complete ruin, works in some cases. Project owners often have insufficient purchasing power to import better quality sands because they are very expensive.

The objective of this article is to assess the quality of sands, derived from weathering coats, in West Cameroon, from the point of view of the resistance, to compression of the concrete produced, with a view to proposing methods, for improving the quality of structures, built with these materials.

The main quarries, providing sand, used in Bafoussam, capital of the region, of West Cameroon, are located in the localities of Batie and Bandjoun. To achieve the objective, it required a physical characterization, sands, from sand pits, Djengou, Hiala, La'gou I in Batie, and those of Djione in Bandjoun.

In West Cameroon, similar work has been carried out by other authors. Etobe [3] studying the alteration mantle sands at Dschang finds that they have poor compressive strength due to the presence of clays. Keyangue [4] in the partial study of the sands of Batie finds sand equivalent values unsuitable for the manufacture of quality concrete. Vouffo's [5] studies on the sands of Baleng's pyroclastic products show that they have good compressive strengths but are unsuitable for the formulation of reinforced concrete. Fofé [6] conducted a comparative study on alluvial sands in Bafoussam with crushed sands from quarries. He concluded that concretes made from quarry sands have better mechanical resistances than concretes made from alluvial sands.

\section{Materials and Methods}

\subsection{Location and Sampling}

Figure 1 shows the maps ( $\mathrm{B}$ and $\mathrm{C}$ ) of localities in the region, West Cameroon, where the materials studied were collected.

The locality of Batie, in the Department, of the Hauts Plateaux, has an area of approximately $85 \mathrm{~km}^{2}$, and is between $5^{\circ} 10^{\prime}$ and $5^{\circ} 22^{\prime}$ north latitude, and $10^{\circ} 15^{\prime}$ and $10^{\circ} 24^{\prime}$ East longitude. The quarries of Djeudem, Djengou, Hiala and La'gou I are there, and are being mined. These quarries are open on interfluves, with convex slopes, located respectively, $2.01 \mathrm{~km}, 1.90 \mathrm{~km}, 2.30 \mathrm{~km}$ and $1.70 \mathrm{~km}$, from national road number 2 [7].

Djeudem's quarry is located between $05^{\circ} 17^{\prime} 21^{\prime \prime}$ North latitude and $10^{\circ} 16^{\prime} 14^{\prime \prime}$ East longitude. This quarry, is open, on an interfluve, which culminates at $1279.10 \mathrm{~m}$ above sea level. Djengou's quarry is located on an altitude of $1413 \mathrm{~m}$; it is identified by the geographic coordinate point, $05^{\circ} 17^{\prime} 01^{\prime \prime}$ North and $10^{\circ} 16^{\prime} 01^{\prime \prime}$ East. 


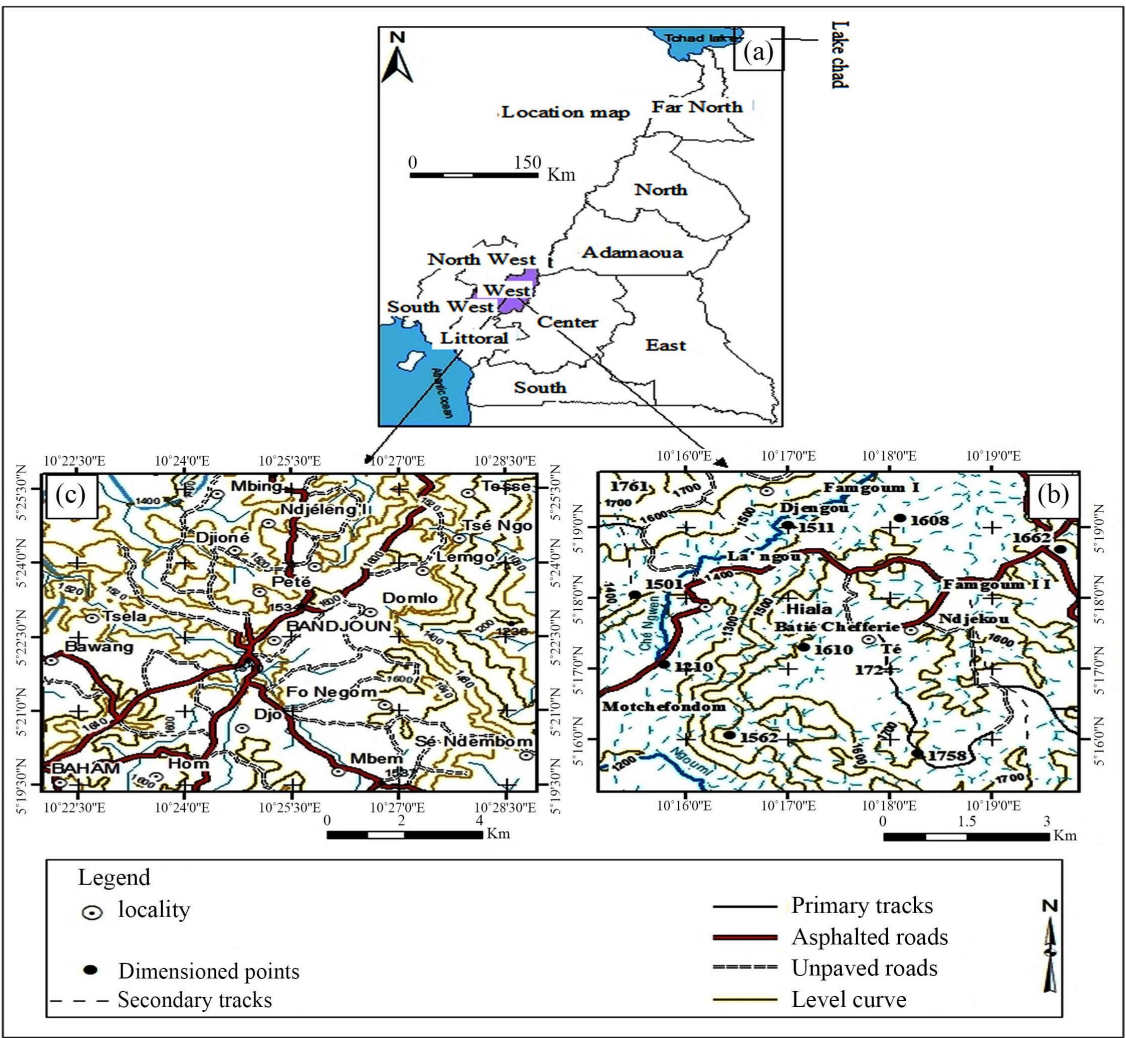

Figure 1. Location map, sampling points, at Batie and Bandjoun, in West Cameroon.

The career; ofHiala is open on an interfluve, of $1637 \mathrm{~m}$ of altitude, which is between, $05^{\circ} 17^{\prime} 50^{\prime \prime}$ North latitude, and at $10^{\circ} 17^{\prime} 55^{\prime \prime}$ East longitude.

La'gou I's quarry opens onto an interfluve, which rises to an altitude of 1510 $\mathrm{m}$. It is located between latitude $05^{\circ} 17^{\prime} 06^{\prime \prime}$ North and longitude, $10^{\circ} 17^{\prime} 07^{\prime \prime}$ East.

B1, D1, H1 and L1 refer to material taken from the upper horizons of Bandjoun-Djione, Djengou, Hiala and La'gou I, respectively, and B2, D2, H2 and L2 refer to material from the lower horizons at the same sites.

Bandjoun's quarry is located in the Djebem district, in the Department of KOUNG-KHI. It is a locality, located at an altitude of $1410 \mathrm{~m}$, south-east of Bafoussam, between $5^{\circ} 16^{\prime}$ and $5^{\circ} 27^{\prime}$ North latitude, and between $10^{\circ} 22^{\prime}$ and $10^{\circ} 37^{\prime}$ East longitude.

The two main extraction sites, sand are located in Djione, respectively $10.5 \mathrm{~km}$ and $14.5 \mathrm{~km}$ from the national road $\mathrm{N}^{\circ} 3$, which crosses Bandjoun.

In these quarries, we exploit weathering products, of a porphyroid granite. The parent rock outcrops, in the form of a dyke, balls or metric blocks, on the slopes of the interfluves [3]. The walls of their profiles show a sufficiently altered material, in the form of a whitish, pinkish powder, which macroscopic examination reveals, a mineralogy of quartz, feldspar and biotite. In these quarries, two horizons of different colors are used separately for the production of sands; the alteration sequence, which goes from the source rock; on the surface humiferous horizon, is perfectly observable.

Sampling, representative in quarries, after extraction and treatment, with wa- 
ter was carried out, according to standard P 18-551 [8]. These samples were used for determination of apparent densities, and absolute, evaluation of the sand equivalent, to the particle size by dry voice analysis, and the preparation of concrete specimens.

\subsection{Experimentation Methods}

The tests were carried out in Cameroon, at the National Laboratory of Civil Engineering, (LABOGENIE) and at the Laboratory of Civil Engineering, of the University Institute of Technology Fotso Victor; University of Dschang.

The sampling of samples in the laboratory was carried out, according to the procedure, prescribed by standard NF EN 932-2 [9]. The apparent density was determined by the hydrostatic balance method, according to standard NF P 94-053 [10]. The absolute density was determined by measuring the volume of the solid grains with a pycnometer and by successive weighings, according to the recommendations of standard NF P 94-054 [11]. The dry density, the porosity, the void index, and the degree of saturation, were determined by calculation, using the relationships which exist between the different; physical parameters [12].

The equivalent of sand has been determined by following washing the prescriptions of the standard, NF EN 933-8 [13]. The particle size analysis was done dry using the NF P 94-050 standard [14]. The formulation of the concretes was made, according to the principle of the Dreux-Gorisse method [15], by targeting a plastic concrete, with a characteristic resistance at 28 days of age of $25 \mathrm{MPa}$, prescribed by LABOGENIE; for standard works in Cameroon. The inspection of fresh concrete was carried out in accordance with standard NF EN 12350-2 [16], while the sampling, preparation and storage of test pieces were carried out in accordance with standards NF EN 12350-1 [17], and NF EN 12390-2 [18], respectively. The preparation of the specimens and the determination of their compressive strength complied with the procedures of the standard EN 12390-3 [19].

\section{Results and Discussion}

\subsection{Physical Properties of Sands}

The physical properties, in particular the densities are presented in Table 1.

It can be seen from Table 1 that the values of the densities determined are between 2.55 and 2.6, which are close to those of quartz. They are of the same order (2.57 and 2.7) as those found by Sonfeu [20] for Bati sands. In the comparative study of Sanaga and Wouri sands and standardized ENV 206-1, Edzoa [21] found absolute values of 2.67 for Sanaga, 2.45 for Wouri and 2.64 for standardized sand.

\subsection{Sand Equivalent, and Particle Size Analysis}

The values, of the sand equivalent, as well as the parameters related to the granularity of the sands studied, are presented in Table 2. 
Table 1. Densities of sands, from the quarries of Bandjoun-Djione, Djengou, Hiala and La'gou I.

\begin{tabular}{ccccc}
\hline $\begin{array}{c}\text { Sampling } \\
\text { career }\end{array}$ & $\begin{array}{c}\text { Naming of } \\
\text { samples }\end{array}$ & $\begin{array}{c}\text { Apparent } \\
\text { density } \boldsymbol{d}_{\boldsymbol{a}}\end{array}$ & $\begin{array}{c}\text { Dry } \\
\text { density } \boldsymbol{d}_{\boldsymbol{d}}\end{array}$ & $\begin{array}{c}\text { Absolute } \\
\text { density } \boldsymbol{d}_{\boldsymbol{s}}\end{array}$ \\
\hline \multirow{2}{*}{ Bandjoun-Djione } & $\mathrm{B} 1$ & 1.40 & & 2.60 \\
Djengou & $\mathrm{B} 2$ & 1.35 & & 2.55 \\
& $\mathrm{D} 1$ & 1.75 & 1.48 & 2.57 \\
Hiala & $\mathrm{D} 2$ & 1.72 & 1.55 & 2.56 \\
& $\mathrm{H} 1$ & 1.70 & 1.43 & 2.58 \\
La'gou I & $\mathrm{H} 2$ & 1.71 & 1.41 & 2.59 \\
& $\mathrm{~L} 1$ & 1.69 & 1.39 & 2.60 \\
\hline
\end{tabular}

Legend: upper horizons (B1, D1, H1, L1); lower horizons (B2, D2, H2, L2).

Table 2. Sand equivalent and finesse module of Bandjoun-Djione sands, Djengoub sands, Hiala sands and La'gou I sands.

\begin{tabular}{cccc}
\hline Sampling career & $\begin{array}{c}\text { Naming of } \\
\text { samples }\end{array}$ & Sand equivalent, ES (\%) & Finesse module (MF) \\
\hline \multirow{2}{*}{ Bandjoun-Djione } & B1 & 58.00 & 3.55 \\
& B2 & 85.46 & 1.83 \\
Djengou & D1 & 64.91 & 3.93 \\
& D2 & 76.40 & 3.08 \\
Hiala & H1 & 67.04 & 2.8 \\
& H2 & 77.30 & 3.33 \\
La'gou I & L1 & 63.34 & 3.80 \\
& L2 & 72.10 & 2.50 \\
\hline
\end{tabular}

Legend: upper horizons (B1, D1, H1, L1); lower horizons (B2, D2, H2, L2).

Table 2 shows that the values of the sand equivalent, the lowest are those of the sands collected, on the upper horizons (B1, D1, H1, L1), of the weathering profiles. They are all less than $70 \%$, which does not classify them among the sands for making quality concrete according to Dreux [15]. These values are lower than those found by Edzoa [21], for the Wouri and Sanaga sands which are better local sands for the formulation of high performance concretes. The sands from the lower horizons (B2, D2, H2, L2), despite the values of their sand equivalent greater than $70 \%$, still require a reduction in fine particles, responsible for the increase in shrinkage, of the concrete [22]. The values of the fineness modules are generally high and are greater than 2.8 (Table 2). These values do not fall within the range of fineness modules defined by Dreux for concrete sands. Such values must be corrected, by adding sand with a smaller fineness module. Indeed, high fineness modulus values cause segregation, and a drop in the mechanical strength of concrete, Keyangue [7]. 
Figure 2 and Figure 3 show the grain size curves of the sands from the upper horizons and the lower profiles respectively. The grain size curves of the sands are compared to the reference granular time zone, for sands suitable for concrete.

Figure 2 and Figure 3 show that, with the exception of the particle size curves of the Hiala sands, all the other particle size curves have almost the same concavity, which testifies to the common origin of the source rock, which generated them.

\subsection{Compressive Strength}

The compressive strengths of concrete specimens at different ages are shown in Table 3.

Table 3 shows that the compressive strengths at 28 days of age are well below the $25 \mathrm{MPa}$ value expected at formulation. They are between $52 \%$ and $70 \%$ of the expected strength. Only Lagou sands (L2) with a fineness modulus of 2.5 have an expected strength coverage of $98.56 \%$.

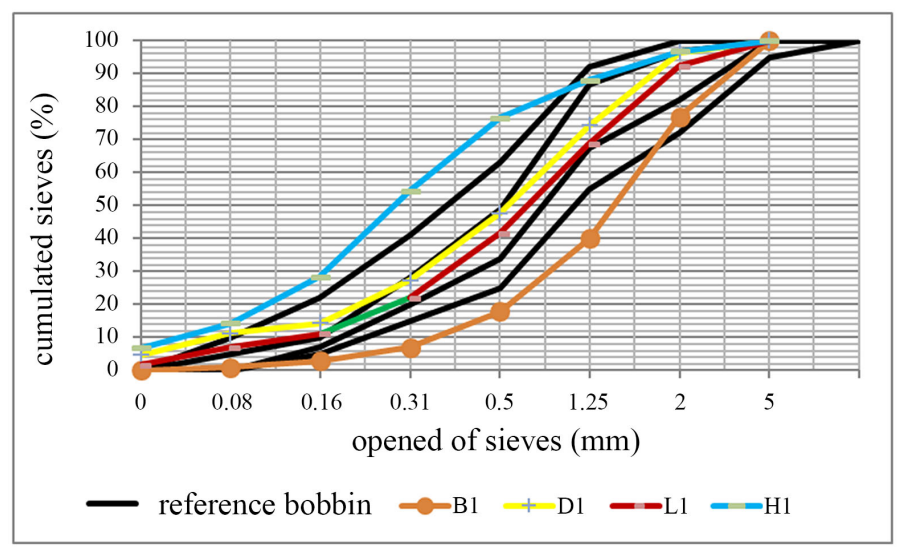

Figure 2. Granulometric curves of the sands, from the upper horizons of the Batie and Bandjoun-Djione quarries, compared to the reference granular spindles.

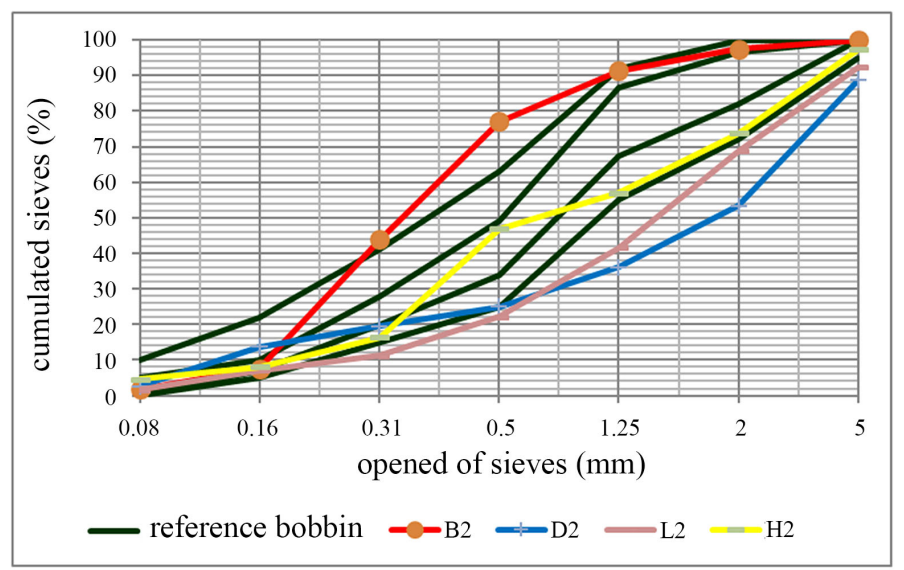

Figure 3. Particle size curves, sands from the lower horizons of the Batie and Bandjoun-Djione quarries, compared to the reference granular zones. 
Table 3. Compressive strength of concrete samples, at different ages, before the particle size correction.

\begin{tabular}{cccccc}
\hline \multirow{2}{*}{ Sampling career } & Naming of & \multicolumn{2}{c}{$\begin{array}{c}\text { Concrete resistance (MPa) } \\
\text { according to its age (in days) }\end{array}$} & $\begin{array}{c}\text { Expected resistance } \\
\text { ramples }\end{array}$ & $\begin{array}{c}\text { rate } 28 \text { days } \\
\text { achieved }\end{array}$ \\
\cline { 3 - 5 } Bandjoun-Djione & B1 & 9.39 & 12.39 & 13.14 & 52.56 \\
& B2 & 10.89 & 13.14 & 14.14 & 56.56 \\
Djengou & D1 & 13.00 & 14.00 & 16.00 & 64 \\
& D2 & 11.74 & 13.08 & 15.06 & 60.24 \\
Hiala & H1 & 10.00 & 11.50 & 17.50 & 70 \\
& H2 & 12.00 & 13.42 & 16.04 & 64.16 \\
La'gou & L1 & 10.00 & 13.00 & 16.50 & 66 \\
& L2 & 14.80 & 18.53 & 24.64 & 98.56 \\
\hline
\end{tabular}

Legend: upper horizons (B1, D1, H1, L1); lower horizons (B2, D2, H2, L2).

Following these results obtained on the concretes made with its sands, a correction of the granulometry was made.

The corrections made from the fineness module abrams rule [15], aiming for an average fineness module of 2.6, made it possible to obtain the values of the proportions of sand, to be taken for each formulation of concrete. The corrective sand chosen, being that of the lower horizon (B2) of Bandjoun-Djione, whose fineness module is equal to 1.83 . Indeed, the process of modifying the fineness module is as follows: if $M f_{1}$ is the fineness module of the sand $1 ; M f_{2}$ the fineness module of sand 2, we can obtain a sand 3, of predefined fineness module $M f_{3}$, $\left(M f_{3}<M f_{1}\right.$ and $\left.M f_{3}>M f_{2}\right)$ by combining the mixture, in the following proportions:

- sand $1=\left(M f_{3}-M f_{1}\right) /\left(M f_{2}-M f_{1}\right)$;

- $\quad$ sand $2=\left(M f_{2}-M f_{3}\right) /\left(M f_{2}-M f_{1}\right)$.

Table 4 presents the proportions in percent of sand to take, in order to have a fineness modulus of contained sand, in the interval between the fineness modules of quality concrete sands according to Dreux.

Table 5 presents the values of the compressive strengths, following the correction of the granularity of the sands, at different ages.

Table 5 shows that, following the correction of the granularity of the sands, the expected compressive strength has been achieved, on almost all of the samples studied. However, it can be seen that the Bandjoun-Djione sand has not reached the expected resistance, although an increase of more than $85.43 \%$ has been observed.

The curves of Figure 4 and Figure 5 show the evolution of the compressive strength of concrete depending on their age.

Figure 4 shows that the resistances to the uni-axial compression of the concrete test pieces, at the age of 28 days, are lower than the value expected during the formulation $(25 \mathrm{MPa}$ ). In Figure 5 (after correction of the grain size distri- 
bution), it can be seen that these resistances have increased, by at least $60 \%$. This increase in resistance is observed following the correction of the granularity of the sands used.

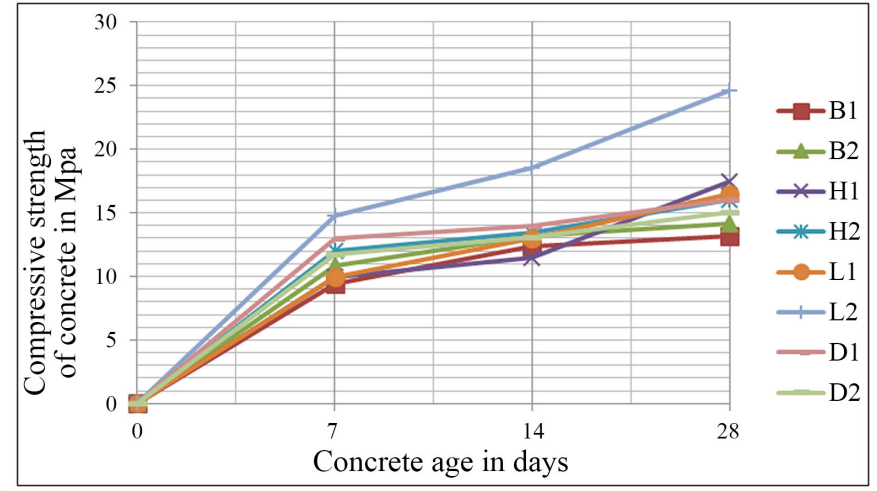

Figure 4. Evolution curve of concrete strengths, before correction of the grain size distribution.

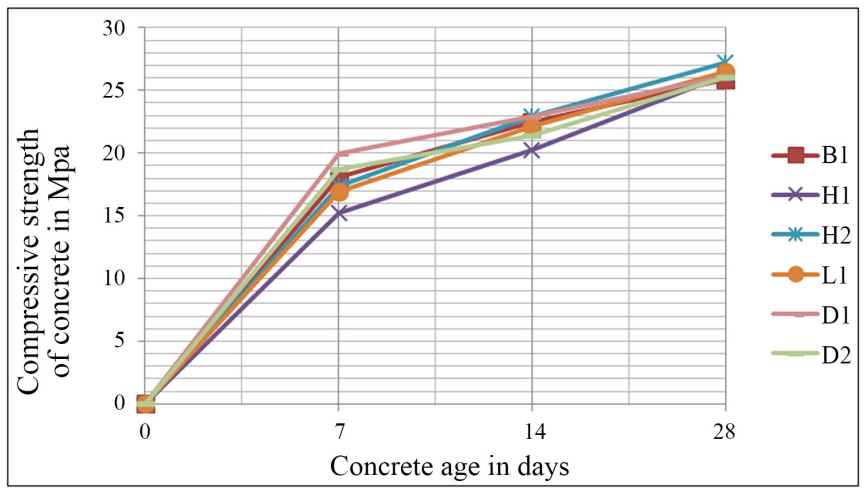

Figure 5. Evolution curve of concrete strengths, after correction of the grain size distribution.

Table 4. Values of the proportions of sand, taken for the correction of the granularity of the sands studied.

\begin{tabular}{cccccc}
\hline $\begin{array}{c}\text { Sampling } \\
\text { career }\end{array}$ & $\begin{array}{c}\text { Naming of } \\
\text { samples }\end{array}$ & $\begin{array}{c}\text { Fineness } \\
\text { module (FM) }\end{array}$ & $\begin{array}{c}\text { Proportions } \\
\text { of sand } \\
\text { collected (\%) }\end{array}$ & $\begin{array}{c}\text { Proportion } \\
\text { of corrective } \\
\text { sand (\%) }\end{array}$ & $\begin{array}{c}\text { Fineness } \\
\text { module, } \\
\text { aimed }\end{array}$ \\
\hline \multirow{2}{*}{ Bandjoun-Djione } & B1 & 3.55 & 44.76 & 55.24 & \\
Djengou & B2 & 1.83 & $/$ & $/$ & \\
& D1 & 3.93 & 36.66 & 63.34 & \\
Hiala & D2 & 3.08 & 61.60 & 38.4 & \\
& H1 & 2.8 & 79.38 & 20.62 & \\
La'gou I & H2 & 3.33 & 51.3 & 48.7 & \\
& L1 & 3.80 & 39.0 & 61.0 & \\
\hline
\end{tabular}

Legend: upper horizons (B1, D1, H1, L1); lower horizons (B2, D2, H2, L2). 
Table 5. Compressive strength of concrete specimens, at different ages, after the correction of the particle size by the Abrams rule.

\begin{tabular}{cccccc}
\hline \multirow{2}{*}{ Sampling career } & Naming of & \multicolumn{2}{c}{$\begin{array}{c}\text { Concrete resistance (MPa) } \\
\text { according to its age (in days) }\end{array}$} & $\begin{array}{c}\text { Expected resistance } \\
\text { rate at 28 days } \\
\text { achieved }\end{array}$ \\
\cline { 3 - 5 } Bandjoun-Djione & B1 & 15.31 & 20.21 & 21.43 & 85.43 \\
\cline { 3 - 4 } Djengou & D1 & 19.93 & 22.97 & 26.11 & 104.44 \\
& D2 & 18.76 & 21.45 & 26.02 & 104.08 \\
Hiala & H1 & 16.31 & 18.75 & 28.54 & 114.16 \\
& H2 & 19.57 & 21.88 & 26.16 & 104.64 \\
La'gou & L1 & 16.91 & 22.16 & 26.52 & 106.08 \\
& L2 & 16.42 & 21.3 & 24.64 & 98.56 \\
\hline
\end{tabular}

Legend: upper horizons (B1, D1, H1, L1); lower horizons (B2, D2, H2, L2).

\section{Conclusion}

The extraction of sands, weathering coats from West Cameroon, is the main source of supply of aggregates for the construction of civil engineering works. The sand equivalent values are less than $75 \%$ and are not suitable for the formulation of high-strength concretes. Fineness modulus values are very high, above 2.8. The strengths of concretes formulated with sand in its natural state are low and range from 13 to $24 \mathrm{MPa}$. The low resistances obtained on concrete specimens, are translated in the field by the low durability and the lack of comfort of civil engineering works. Nevertheless, it emerges from the present study, that a correction of the granulometry, by the combination of the sands of the lower horizon (B2), of the sand of the Bandjoun-Djione quarry, whose fineness modulus is equal to 1,83 , with sands from other quarries (Bandjoun-Djione sand square, horizon B1; Djengou sand quarry, horizons D1 and D2; Hiala sand quarry, horizons $\mathrm{H} 1$ and $\mathrm{H} 2$; La'gou sand quarry I, horizon L1), of different fineness modules, by targeting the fineness module of 2.6 for the combination, contributes largely to the improvement of mechanical strengths by $60 \%$, as well as to better comfort and durability of civil engineering works. Better washing of these sands in the quarry, before placing them on the market, would improve their equivalent of sand.

\section{Future Prospects}

An analysis of the chemical composition of these sands would highlight the mineral phases present there, and likely to interact with the cement paste, to cause the concrete to swell and burst.

\section{Conflicts of Interest}

The authors declare no conflicts of interest regarding the publication of this paper. 


\section{References}

[1] P 18-560 September 1990 Aggregates Particle Size Analysis by Sieving.

[2] Ershov, V.V., Novikov, A.A. and Popova, G.B. (1988) Fundamentals of Geology. Mir Publisher, Moscou, 358 p.

[3] Etobe, J.M. (1999) Influence of Sand Types in Dschang on the Strength of Concrete. Dissertation of Agricultural Engineer, FASA, University of Dschang, Dschang, $54 \mathrm{p}$.

[4] Keyangue, T.J.H. (2007) Physical Characterization of Sands from Alteration Coats on Batie Granite (West Cameroon) and Improvement of Their Quality in the Making of Concrete. Dissertation, Master's Degree, University of Dschang, Dschang, 78 $\mathrm{p}+$ appendix.

[5] Vouffo, M., Kamga, D.T., Ngapgue, F. and Kemtchou, F.H. (2020) Mechanical Characterization of Pyroclastic Products for Use in Civil Engineering Works. Journal of Mechanical and Civil Engineering, 17, 35-43.

[6] Fofe, M.C. (2016) Étude comparative des sables pour une meilleure optimisation de la formulation des bétons hydrauliques: Cas des sables alluvionnaires de la Sanaga, des sables carrières de Bamoungoum et d'Arab Contractor d'Eloumdem. Mémoire de Master, Université de Ngaoundere, Ngaoundere, 80 p.

[7] Keyangue, T.J.H. (2016) Physical, Geochemical, Mineralogical and Mechanical Characterization of Sands from the Alteration Mantle of Batié Granites (West Cameroon) and Improvement of Their Potential as Construction Materials. Ph.D. Thesis, University of Dschang, Dschang, 135 p. + Appendices.

[8] P18-551 December 1990 Withdrawal of Materials from Stocks.

[9] NF EN 932-2 (1999) Tests for Determination of General Aggregate Properties Part 2: Methods for Reduction of a Laboratory Sample.

[10] NF P 94-053 (1991) Soils: Recognition and Testing. Determination of the Density of Fine Soils in the Laboratory. Cutting Kit, Mould and Water Immersion Method. AFNOR, Paris.

[11] NFP 94-054 (1991) Soils: Recognition and Testing. Determination of the Density of Solid Particles. Water Pycnometer Method. AFNOR, Paris.

[12] Robitaille, V. and Tremblay, D. (1997) Soil Mechanics (Theory and Practice). Modulo, Quebec, 652 p.

[13] NF EN 933-8 (1999) Tests for Determining the Geometric Characteristics of Aggregates Part 8: Evaluation of Fines-Sand Equivalent.

[14] NF P 94-056 (1995) Soils: Recognition and Testing. Particle Size Identification-Dry Sieving Method. AFNOR, Paris.

[15] Dreux, G. (1976) New Concrete Guide. Ed. Eyrolles, 292 p.

[16] NF EN 12350-2 (1999) Test for Fresh Concrete Part 2: Slump Test.

[17] NF EN 12350-1 (1999) Test for Fresh Concrete Part 1: Sampling.

[18] NF EN 12390-2 (2001) Test for Hardened Concrete Part 2: Production and Storage of Specimens for Strength Tests.

[19] EN 12390-3 (2001) Tests for Hardened Concrete-Part 3: Compressive Strength of Test Pieces.

[20] Sonfeu, M.B. (2017) Physical Characterization of Alluvial Sands from the Noun River and Its Tributaries: Case of the Locality of Bati (West-Cameroon). Thesis Presented for the Diploma of Engineer of Mines-Mineralurgy-Environment, University of Ngaoundéré, Ngaoundéré, 40 p. + Annexes. 
[21] Edzoa, A. (2018) Comparative Study of the Properties of the Sands Extracted from the Sanaga and Wouri Rivers and the Sand Normalized in 196-1. Thesis Presented for the Diploma of Engineer of Mines-Mineralurgy-Environment, University of Ngaoundéré, Ngaoundéré, 47 p. + Annexes.

[22] Ngapgue, F., Wouatong, A.S.L., Kabeyene, B.K.V. and Keyangue, T.J.H. (2009) Physical Characterization of Batie Sand (West-Cameroon) and Its Correction: Case Study of Mount Metchou. Journal of Solid and Structures, 3, 125-136. 